\title{
Determination of quality changes of fish sausage produced from saithe (Pollachius virens L., 1758) during cold storage
}

\section{Mezgitten (Pollachius virens L., 1758) ürretilen balık sosislerin soğuk muhafaza sırasındaki kalite değişimlerinin belirlenmesi}

\section{Tolga Dinçer* (D) E. Burcu Şen Yılmaz • Şükran Çaklı \\ Department of Fishery and Processing Technology, Faculty of Fisheries, Ege University, İzmir, Turkey \\ *Corresponding author: tolga.dincer@ege.edu.tr}

How to cite this paper:

Dinçer, M.T., Yılmaz, E.B.Ş. S. \& Çaklı, Ş. (2017). Determination of quality changes of fish sausage produced from saithe (Pollachius virens L., 1758) during cold storage. Ege Journal of Fisheries and Aquatic Sciences, 34(4):391-399. doi: 10.12714/egejfas.2017.34.4.05

Abstract: The objectives of this study were to determine the texture and quality parameters of surimi sausage which was prepared from saithe flesh, during the cold storage. First stage was the production of surimi by using saithe flesh (Pollachius virens) and second stage was preparation of fish sausage and monitoring its quality during the cold storage condition. Quality parameters of prepared sausages were determined by using chemical (Total Volatile Base Nitrogen $\mathrm{mg} / 100 \mathrm{~g}$, Tiyobarbutric acid $\mathrm{mg}$ malonaldehyde/kg and pH analyses), microbiological (Total Aerobic Mesophilic Bacteria Count, Psycrophilic Bacteria Count, Anaerobic Bacteria Count, Staphylococcus aureus count and Yeast - Mould) and sensorial analysis. The mechanical parameters were observed by using texture profile analysis (TPA) and shear test during the storage period at $0,+4^{\circ} \mathrm{C}$. Spoilage was detected due to the microbiological analysis results on the $15^{\text {th }}$ day of storage.

Keywords: Texture, quality, surimi, fish, sausage, colour measurement, saithe

Öz: Bu çalışmanın amacı soğuk depolamada mezgit etinden üretilen surimiden yapılan sosis dokusunu ve kalite parametrelerini tespit etmektir. Birinci aşamada mezgit filetolarından (Pollachius virens L., 1758) surimi üretimi gerçekleştirilmiş ve çalışmanın ikinci aşamasında ise hazırlanan surimi ham materyalinden sosis üretimi gerçekleştrilmiş ve soğuk muhafaza koşullarında kalite değişimleri gözlemlenmiştir. Hazırlanan sosislerin kalite parametreleri kimyasal (Toplam Uçucu Bazik Azot mg/100gr, Tiyobarbutiric asid miktarı mg malonaldehit/kg ve pH analizleri) mikrobiyolojik (Toplam Aerobik Mezofilik Bakteri sayısı, Psikrofilik Bakteri SayıII, Anaerobik Bakteri sayısı, Staphylococcus aureus sayısı ve Maya -Küf) ve duyusal analizler kullanılarak tespit edilmişstir. Mekanik parametreler ise $0,+4$ ${ }^{\circ} \mathrm{C}$ 'de depolama süresi boyunca doku profili analizi (TPA) ve kesme testi kullanılarak gözlemlenmiştir. Depolama 15. günde yapılan mikrobiyolojik analiz sonuçlarına göre bozulma tespit edilmiştir.

Anahtar kelimeler: Doku, kalite, surimi, balık, sosis, renk ölçümü, mezgit

\section{INTRODUCTION}

Surimi is a Japanese term, which defines a concentrate of myofibrillar proteins obtained after mincing and water washing of fish flesh (Park and Morrissey, 2000; Toyoda et al. 1992). Surimi is light in color, has a bland odor, low in fat and high in myofibrillar protein and extremely functional due to the unique gelling properties of these myofibrillar proteins and these qualities make surimi an ideal and useful ingredient for fabricating new food products (Lee, 1986). Surimi is the term used for minced fish in which, most of the water-soluble components, including sarcoplasmic proteins have been removed by leaching with water (Murakawa et al., 2003). Surimi process functionality including gelling, binding, and emulsifying properties can be used as a functional protein ingredient in several products (Lanier, 1986). Surimi which is a highly functional protein raw material, is one of the most famous and preferred Japanese seafood for production technologies (Kim and Park, 2006). Surimi can be used as raw material for a variety of popular food products such as fish ball, fish noodles, fish sausage, fish burger or fish cakes. Thus, gelling properties of surimi can be influenced by many factors causing the structural alteration in sausage (Jin et al., 2007). This version of sausage development is very important not only for consumers but also for the seafood industry. Fish is known as a rich source of long-chain $n-3$ fatty acids, and those fatty acids are known to have a range of health benefits. Especially potential roles in reducing the risk of coronary heart disease, inflammatory disorders, and immune disorders have resulted in interest among consumers and manufacturers (DeDeckere et al., 1998; Trautwein, 2001). Besides, emulsified fish products like salami and sausage can be other alternatives for food 
manufacturers. Minced fish and surimi/surimi powder have been used as raw materials for emulsion sausage production for many years, especially in Asian countries (Konno, 2005). All over the world the health organisations recommend limiting the intake of saturated fatty acids and cholesterol (Kris-Etherton et al., 1988). The best solution might be to encourage consumers to consume fish-based products.

Several recent studies have examined the use of various functional ingredients or adjuncts in sausage formulations. Among such ingredients are starch (Shand, 2000), egg white (Carballo et al., 1996), salt (Ripoche et al., 2001), carrageenans (Hughes et al., 1997), other gums (Xiong et al., 1999) and konjac flour (Chin et al., 1998).

The aim of this study was to produce a surimi and sausage from saithe (Pollachius virens L., 1758) fillets and determining the quality changes of sausage product during cold storage. Achieving a pleasant appearance and an extended shelf life without loss of the traditional spicy sausage taste and the reduction of nitrate content were the main goals of the product.

\section{MATERIALS AND METHODS}

\section{Raw Material}

Frozen saithe fillets (Pollachius virens L., 1758) which have skins were used as raw material in this study. It was known that the frozen fillets were imported from Norway by the Pınar Company (Izmir, Turkey) 2 months before and have been stored in $-24^{\circ} \mathrm{C}$ up to the beginning of the study. Frozen samples were transported to the PInar Et R\&D laboratory in the frigorific vehicle $\left(-18^{\circ} \mathrm{C}\right)$ from the company freezing storage unit the night before the production.

\section{Surimi production}

Traditional method of surimi production technique was preferred for the production. Frozen saithe fillets (Polachius virens. L., 1758) were were thawed up to $-2{ }^{\circ} \mathrm{C}$ before the sarcoplasmic tissues were removed. First skins were removed, then myofibril proteins were separated from dark flesh and deboned by hand and then they were washed to remove any remaining slime, scales or blood adhering to the flesh. Cleaned fish flesh was next minced by using Kitchen Aid KPM5 Professional meat grinder (St. Joseph, Michigan, USA), equipped with $2 \mathrm{~cm}$ grinding blades and a metallic screen with six mm diameter circular holes. Minced flesh was washed in a stainless-steel tank with iced water $(1 / 1 \mathrm{w} / \mathrm{v})$ in the ratio of one part flesh to three parts water (w/v) and gently stirred for a residence time of $5 \mathrm{~min}$. Dewatering was achieved by wrapping surimi inside of a cheese cloth and squeezed by using screw press. That process of washing and dewatering was repeated two times in the production steps. Then the final wash (third wash) was done by adding $0.1 \%$ salt and ice $(\mathrm{w} / \mathrm{w})$ to finalize the dewatering process. As additives cryoprotectants; 4\% (w/v) sorbitol and $4 \%$ (w/v) polyphosphate were added and blended by using a bowl chopper (Mainca Bowl Chopper, Maquinaria Industria, Barcelona, Spain) to complete the process. Surimi temperature was maintained lower than $8^{\circ} \mathrm{C}$ throughout the process. Surimi was formed into blocks, over wrapped with oxygen permeable polyvinyl-chloride film and kept in frozen storage at $-18^{\circ} \mathrm{C}$ for two days before the process of sausage production.

\section{Casing material}

Cellulose sausage casings (Wienie-Pak®, Belgium) were used for the processing fish sausage. The physical property of casing material was $21 \mathrm{~mm}$ diameter (no:19), $15 \mathrm{~cm}$ long and colorless. This material can hold up to $4.5 \mathrm{~kg}$ of filling. During the pasteurization process, this cover material can protect the physical and chemical properties of its content.

\section{Formulation}

The formula and the ingredients for production were as follows: raw surimi material, $67.84 \%$; ice, $16.28 \%$; cow fat, $5.09 \%$; sun flower oil, $5.09 \%$; soy protein concentrates (SN 650, Heilongjiang Shuanghe Songnen Soybean Bioengineering Co., Ltd., Heilongjiang, China), 1.7\%; modified potato starch (PenCling® 530, Penford Food Ingredient CO, Colorado, USA); $1.7 \%$; salt, $1.36 \%$; sodium tripolyphosphate (STPP), $0.17 \%$; red pepper, $0.07 \%$; black pepper, $0.14 \%$; sugar, $0.15 \%$; pimento, $0.04 \%$; coriander, $0.10 \%$; ginger, $0.10 \%$; ascorbic acid, $0.02 \%$; sodium nitrite, $0.02 \%$; coloring, $0.02 \%$, MSG, $0.14 \%$. Sausage formula was taken from the National Patent No: TR 2009 02207B (Dincer and Cakli, 2012).

\section{Sausage production}

Frozen surimi was tempered with room temperature for $2 \mathrm{~h}$ and optimized formulations for fish-surimi sausage were prepared in a bowl chopper. The appropriate quantities of the various ingredients were weighed in order to produce $15 \mathrm{~kg}$ of batter. Sausage batter was prepared in sequential steps as follows. First minced surimi was mixed with salt and STPP for 2 min with an industrial bowl cutter (15 kg capacity; Mainca Bowl Cutter Model C-14, Berkshire, UK). During mixing batter temperature was recorded as $-2.24 \pm 1.02{ }^{\circ} \mathrm{C}$. In the second step, ice-water ( $1 / 3$ of the total ice), soy protein concentrates and potato starches were added with additional mixing for 1 min. Thereafter, cow fat and sun flower oil were added separately and mixed for one min each. Spices and another $1 / 3$ of total ice were added. The last step involved the addition of the leftover additives and preservatives and the unused icewater. Additional mixing for 2 min at the same speed was done. The comminuted batter was stuffed into a No.19 cellulose casing using a hydraulic filler (model EC-12A, Mainca Sausage Fillers, Berkshire, UK). Each sausage unit was sized as $50 \mathrm{~g}$ by using an automatic clipping and filling apparatus. The stuffed casing was linked in $20 \mathrm{~cm}$ length and cooked in $85{ }^{\circ} \mathrm{C}$ convection oven (model FKG-042, Inoksan Industrial Equipments, Bursa, Turkey) with $75{ }^{\circ} \mathrm{C}$ internal temperature (measured by a thermocouple probe) held for $35 \mathrm{~min}$. Upon cooking, the sausages were immediately cooled in ice-water $(1: 1, w / v)$ and the casings were removed by hand. Sausages were over wrapped in oxygen permeable (6000-8000 $\mathrm{cm}^{3} / \mathrm{m}^{3} / 24 \mathrm{~h}$ at STP) polyvinyl-chloride film (Wrap Film 
Systems Ltd., Halesfield 14, Telford TF7 4QR, Shropshire, England) by using vacuum packaging technique and the second pasteurization was done by placing inside of a boiling water for $15 \mathrm{~min}$ to protect the product from cross contamination then kept in cold storage $\left(1.14 \pm 1.1^{\circ} \mathrm{C}\right)$ to monitor the conditions for the duration of the trial ( 15 days).

\section{Proximate Composition}

Moisture content was determined by drying the samples at $105^{\circ} \mathrm{C}$ to a constant weight (AOAC, 1990). Crude protein content was calculated by converting the nitrogen content as determined by Kjeldahl's method (AOAC, 1995). Crude fat was determined by using the method described by Bligh and Dyer (1959). The crude ash content was determined by using the method of Ludorff and Meyer (1973). The analysis of the samples were all carried out in triplicate.

\section{Chemical Analysis}

Total volatile basic nitrogen (TVB-N, mg/100g) was determined according to the method of Vyncke (1996). Thiobarbituric acid (TBA, mg malonaldehyde/ $\mathrm{kg}$ ) was determined according to the method proposed by Tarladgis et al. (1960). The pH value was recorded by using a Hanna 211 models pH meter (Cluj-Napoca, Romania), and the glass electrode was applied directly to the homogenate $(5 \mathrm{~g}$ of fish $/ 5 \mathrm{ml}$ distilled water).

\section{Microbiological Analysis}

Microbiological counts were performed for Total Aerobic Mesophilic Bacteria Count (TAMBC) (Harrigan and McCance, 1976) and Total Aerobic Psychrotrophic Bacteria Count (TAPBC) (Ariyapitun et al., 1999). $10 \mathrm{~g}$ of sample was taken and transferred in $90 \mathrm{ml}, 0.1 \%$ peptone water (Difco, 0118-17$0)$. Other decimal dilutions were prepared from the 10-1 dilution. The inoculated plates were incubated at $30 \pm 1^{\circ} \mathrm{C}$ for 48 $\pm 3 \mathrm{~h}$ and at $4^{\circ} \mathrm{C}$ for 14 days for total aerobic mesophilic counts and psychrophilic counts respectively. Anaerobic Bacteria Count (ABC) (FDA,1992), Staphylococcus aureus Count (Mossel and Moreno Garcia, 1985) Yeast and Mould Count (Harrigan and McCance, 1976), used as methods for determining the microbiological quality of the sausage. The number of anaerobic bacteria was determined as pour plate counts in PCA but incubation was carried out in anaerobic jar, for 5 days at $25 \circ \mathrm{C}$. Yeast Extract Glucose Chloromphenicol Agar was used for moulds-yeast count and plates were incubated at $25^{\circ} \mathrm{C}$ for 5 days.

\section{Colour Measurement}

The colour measurement was carried out using the Schubring (2002) method by measuring 10 times of different parts of the upper smooth surface. In the CIE Laboratory system, $L{ }^{*}$ indicates the intensity of light in black from 0 to 100 scales; $a^{*}(+)$ red or $(-)$ green; and $b^{*}(+)$ indicates yellow or (-) blue.

\section{Texture Profile Analysis (TPA)}

TPA was performed using the TA-XT Plus texture analyzer (Stable Micro Systems, Godalming, UK) according to Schubring (2003) method. Prior to the test, the sausage samples were equilibrated to room temperature for 30 minutes and sectioned into a $2 \mathrm{~cm}$ thick layer drawn into a $2.5 \mathrm{~cm}$ diameter cylinder. The samples were compressed twice in a cross speed of $0.80 \mathrm{~mm} /$ second to $60 \%$ of the original height. The mechanical properties of hardness, cohesiveness, springiness, resilience and chewiness were evaluated from the resulting force/deformation curves.

\section{Shear Test}

Specimen loading, test conditions and specimen preparation followed the procedure described by Su et al. (2000). The samples were compressed once at a crosshead speed of $0.80 \mathrm{~mm} / \mathrm{second}$ to cut the whole sausages by using the Warner-Bratzler blade set with a $25 \mathrm{~kg}$ load cell. Shear force and the work of shearing samples were estimated with a Warner-Bratzler blade attached to the same texture analyser. Maximum force to cut the sample (shear force) and the work needed to move the blade through the sample (work of shearing) were recorded.

\section{Sensory Analysis}

Sensory evaluation of the sausage was conducted after the first day of storage following the procedures by FernándezFernandez et al. (2002) using a panel of 5-7 individuals from Ege University Fisheries Faculty, Department of Seafood Processing Technology who are familiar with the sensory assessment of seafood products. In each session, each panelist received 3 whole sausages. The samples were presented in a randomized order to the 5 panelists. The descriptors considered were appearance, visible fat, perceived hardness, fish odour, spicy odour, spoiled odour, taste, fattiness, juiciness, acid taste, bitterness, and rancidity. Sensorial panel score of 5 was defined as the limit of acceptance for some attributes (appearance, hardness and taste). Rest were the amount of the attributes assessed by the panelists. All properties were evaluated on 10-point intensity scales (ISO-4121-1987, 1987).

\section{Statistical analysis}

Statistical analysis was carried out using SPSS (SPSS, 1999, Version 9.0. Chicago, IL, USA) by Duncan's multiple range test. One Way Anova test was used to compare the differences among means between the analysis periods and results. The results are presented as means $\pm S D$ with the significance level set at $p<0.05$ and defined as different superscript letters represents significant difference $(p<0.05)$ during the storage period in tables. 


\section{RESULTS AND DISCUSSIONS}

\section{Assessment proximate composition}

The concentrations of the constituents in sausages used in these experiments, and their means show $51.92(\mathrm{~g} / 100 \mathrm{~g})$ moisture; $1.94(\mathrm{~g} / 100 \mathrm{~g})$ crude ash; $17.34(\mathrm{~g} / 100 \mathrm{~g})$ crude protein and $11.44(\mathrm{~g} / 100 \mathrm{~g})$ crude fat. These results were similar to the study reported by Dincer (2008) about fish sausages. In the study of Dincer et al. (2007) the proximate composition values of prepared fish sausages were reported as $52.73(\mathrm{~g} / 100 \mathrm{~g})$ moisture, $1.97(\mathrm{~g} / 100 \mathrm{~g})$ ash, $19.60(\mathrm{~g} / 100 \mathrm{~g})$ protein and 12.28 $(\mathrm{g} / 100 \mathrm{~g})$ crude fat and these results were similar to the results in the study of Cardosa et al. (2008).

\section{Assessment of chemical analysis}

The TBA index is a widely used indicator for the assessment of the degree of lipid oxidation (Nishimoto et al., 1985). According to Schormüller (1969), the TBA value should be less than $1 \mathrm{mg}$ malonaldehyde/kg for "excellent" quality, 3 mg for "very good" quality, and 3-5 mg for "good" quality. It has been proposed that the acceptability limit of TBA value for consumption is $8 \mathrm{mg}$ malonaldehyde $/ \mathrm{kg}$. TBA values increased $(P<0.05)$ in samples over time indicating an increase in lipid oxidation. TBA values of the samples can be seen in Table 1 . By the end of the storage period no spoilage was detected according to the TBA test on sausage. The changes of TBA values were negligible for the 15 days retail period (Table 1) Normally, lipid oxidation in muscle systems is initiated at the membrane level in the intracellular phospholipid fractions (Gray et al.1996). This may be due to the fact that, susceptibility to lipid oxidation is closely related to fat levels like in the study of Murphy et al. (2004) in their study different fat levels brought different lipid oxidation values in the same conditions. Using lower values of fat and oil causes lower TBA values during the storage in the current study.

TVB-N is a spoilage index for fish and seafood (FAO 1986). FAO has indicated that samples with less than $25 \mathrm{mg} \mathrm{N} / 100 \mathrm{~g}$ TVB-N values are 'perfect quality', samples with up to $30 \mathrm{mg}$ N/100g TVB-N value are 'good quality', samples with up to 35 mg N/100g TVB-N are 'marketable quality' and the samples with more than $35 \mathrm{mg} \mathrm{N} / 100 \mathrm{~g}$ TVB-N value are indicated as 'spoiled' (Schormuller 1968; Ludorff \& Meyer, 1973). At the beginning of the storage period TVB-N values of the samples were determined as $13.60 \pm 0.51 \mathrm{mg} \mathrm{N} / 100 \mathrm{~g}$ whereas the TVB$\mathrm{N}$ values of raw fillets were $10.20 \pm 0.63 \mathrm{mg} \mathrm{N} / 100 \mathrm{~g}$ (Frozen fillet). These values improved fressness of the fish at the beginning of preparation. However, TVB-N values of the samples were still found under the limits on $15^{\text {th }}$ day. The $\mathrm{pH}$ values of samples showed a significant decrease over the 15 days of shelf life evaluation.
The $\mathrm{pH}$ values were recorded in the range of $6.68-6.87$. Chemical tests showed that oxidation of the product was negligible or not present at all, and the $\mathrm{pH}$ was observed to decline and volatile compounds increased during the storage period but not reached the spoilage limits.

Table 1. Chemical quality analysis results of fish sausage during storage

\begin{tabular}{|c|c|c|c|}
\hline Days & $\begin{array}{c}\text { TVB-N } \\
(\mathrm{mg} / 100 \mathrm{~g})\end{array}$ & $\begin{array}{c}\text { TBA } \\
\text { (mgMDA/kg) }\end{array}$ & $\mathrm{pH}$ \\
\hline $\mathrm{T} 1$ & $13.60 \pm 0.51^{\mathrm{a}}$ & $0.31 \pm 0.03^{a}$ & $6.68 \pm 0.09 a$ \\
\hline T3 & $15.96 \pm 0.89 b$ & $0.36 \pm 0.01^{a}$ & $6.77 \pm 0.03 \mathrm{ab}$ \\
\hline T6 & $16.26 \pm 1.02^{b}$ & $0.42 \pm 0.00^{b}$ & $6.79 \pm 0.06^{a b}$ \\
\hline T8 & $17.73 \pm 0.89^{b d}$ & $0.45 \pm 0.04^{b c}$ & $6.81 \pm 0.01^{b}$ \\
\hline $\mathrm{T} 10$ & $19.80 \pm 0.51^{\mathrm{cd}}$ & $0.48 \pm 0.02^{c}$ & $6.84 \pm 0.04^{b}$ \\
\hline $\mathrm{T} 13$ & $20.39 \pm 0.89^{c}$ & $0.50 \pm 0.01^{c}$ & $6.85 \pm 0.01^{b}$ \\
\hline $\mathrm{T} 15$ & $21.28 \pm 0.89 c$ & $0.65 \pm 0.01^{d}$ & $6.87 \pm 0.01^{b}$ \\
\hline
\end{tabular}

Different superscript letters within the same column represents significant difference $(p<0.05), n=3$

\section{Microbiological Analysis}

Microbiological quality control analysis was used in three stage of process. The first sample was taken from the prepared surimi material and the determined counts were $2.96 \mathrm{log} \mathrm{cfu} / \mathrm{g}$ for TAMBC and $2.85 \mathrm{log}$ cfu/g for PBC. In the second step of the sausage process sample was taken from the prepared batter. The taken data was significantly higher $(p<0.05)$ and surimi samples (raw material) and TAMBC and PBC counts were 5.59 log cfu/g, $4.30 \mathrm{log}$ cfu/g respectively, as expected. In the last step of microbiological quality control samples were taken from double pasteurized sausage samples during the cold storage $\left(4^{\circ} \mathrm{C}\right)$. The initial bacterial loads were determined lower than the loads of batter. As expected, determined low load was the result of termal treatment (pasteurization). The bacterial counts of Total Aerobic Mezophilic Bacteria Counts (TAMBC), Psychrotrophic Bacteria Counts (PBC), Anaerobic Bacteria Counts (ABC), Yeast-Mould Counts (YMC) and Staphylococcus aureus loads can be seen in Table 2 . Sausages on the day $15^{\text {th }}$ exceeded 6 log cfu/g, due to the Total Mezophilic Bacterium Counts sausages exceeded the 6 log $\mathrm{cfu} / \mathrm{g}$ value on the $15^{\text {th }}$ day of storage, which was the maximum limit of bacterial load for the acceptability on seafood products (ICMSF 1978). Yeast-Mould counts and Salmonella aureus were observed, neither in raw surimi material nor sausage product during the storage period. In another study, which was about production of sausages using Tilapia nilotica fillets showed similar results (Orellana et al., 1999). Similar results can be seen in the study of Dincer et al. (2007). In both studies pathogenic microorganisms and yeast-mould counts were not detected. 
Table 2. Microbiological quality analysis results of fish sausage during storage (log cfu/g)

\begin{tabular}{llllcc}
\hline Days & $\begin{array}{l}\text { TAMBC } \\
\log \mathrm{cfu} / \mathrm{g}\end{array}$ & $\begin{array}{l}\text { PBC } \\
\log \mathrm{cfu} / \mathrm{g}\end{array}$ & $\begin{array}{l}\text { ABC } \\
\log \mathrm{cfu} / \mathrm{g}\end{array}$ & $\begin{array}{l}\text { YMC } \\
\log \mathrm{cfu} / \mathrm{g}\end{array}$ & $\begin{array}{l}\text { Staphylococcus } \\
\text { aureus }\end{array}$ \\
\hline T1 & $3.17 \pm 0.06^{\mathrm{a}}$ & $2.00 \pm 0.00^{\mathrm{a}}$ & $3.32 \pm 0.09^{\mathrm{a}}$ & $\mathrm{ND}$ & $\mathrm{ND}$ \\
T3 & $3.27 \pm 0.07^{\mathrm{a}}$ & $3.54 \pm 0.03^{\mathrm{b}}$ & $3.18 \pm 0.03^{\mathrm{b}}$ & $\mathrm{ND}$ & $\mathrm{ND}$ \\
T6 & $3.60 \pm 0.06^{\mathrm{b}}$ & $3.85 \pm 0.02^{\mathrm{c}}$ & $3.20 \pm 0.06^{\mathrm{ab}}$ & $\mathrm{ND}$ & $\mathrm{ND}$ \\
T8 & $3.90 \pm 0.01^{\mathrm{c}}$ & $4.36 \pm 0.06^{\mathrm{d}}$ & $3.78 \pm 0.03^{\mathrm{c}}$ & $\mathrm{ND}$ & $\mathrm{ND}$ \\
T10 & $4.62 \pm 0.02^{\mathrm{d}}$ & $4.89 \pm 0.02^{\mathrm{e}}$ & $3.91 \pm 0.01^{\mathrm{d}}$ & $\mathrm{ND}$ & $\mathrm{ND}$ \\
T13 & $5.77 \pm 0.02^{\mathrm{e}}$ & $5.73 \pm 0.01^{\mathrm{f}}$ & $4.30 \pm 0.00^{\mathrm{e}}$ & $\mathrm{ND}$ & $\mathrm{ND}$ \\
T15 & $6.32 \pm 0.04 \mathrm{f}$ & $6.08 \pm 0.08^{\mathrm{a}}$ & $4.77 \pm 0.04^{\mathrm{f}}$ & $\mathrm{ND}$ & $\mathrm{ND}$ \\
\hline rent superscript letters within the same column represents significant difference $(\mathrm{p}<0.05), \mathrm{n}=3$. ND=Not determined
\end{tabular}

\section{Assessments of textural properties}

The mean texture scores from the Texture Profile Analyse (TPA) tests press peak values are indicated in Table 3. As seen in table, hardness and chewiness, in this fish-based product, had values between 29.65-33.92 $(\mathrm{N})$ and 3.97-4.65 (Nmm), respectively. These results were lower than the study of Llull, et al. (2002) and the similar with the study of Dincer (2008). On the other hand, when compared with the research of Dincer and Cakli (2010) which was about the textural properties of rainbow fish sausage produced from frozen fillets the determined values were harder and less chewable than their findings. The determined, hardness values of the sausage decreased slightly up to the end of the first ten days and then increasing values were observed until the end of storage period. Significant differences $(P<0.05)$ are shown in the middle of the storage period when compared with initial days and the end of the period. These results indicated that the hardness value of surimi sausage samples gradually increased by increasing storage time (days). Cohesiveness is a measure of the degree of difficulty to break down the internal structure of the sausages. The cohesiveness of sausage samples varied between 0.18 and 0.23 . Cohesiveness data from the first day of storage were showed a slight similar with no significant difference $(P>0.05)$ except the $13^{\text {th }}$ day value. In general, the addition of water and ice in sausage preparation made the structure softer and less breakable supported by the evidence of the data observed before.
Springiness represents the extent of recovery of sausage height and sometimes referred to as "elasticity" (Sanderson 1990). The springiness of the sausage samples did not differ significantly at all between the periods. In the chewiness values of samples decreasing values can be observed in the first week but after that increasing values were observed. These results were inconsistent with those reported by other investigations which demonstrated that the addition of soy protein, or starch improved the textural properties by decreasing hardness in the product (Dawkins et al., 2001; Ho et al., 1997, Prabhu and Sebranek, 1997). Carballo et al. (1996) found only small differences in cohesiveness among bologna sausages made using different amounts of added oat, starch and egg white. Lee and Toledo (1976) observed that marked reduction in compressive strength and increase in shear strength occurred in Spanish mackerel sausages after frozen stored and the extent of the change became more pronounced as moisture content increased. They also reported the improvement of texture with addition of shortening ( $12 \mathrm{~g} / 100 \mathrm{~g}$ muscle) and soy protein fiber $(15 \mathrm{~g} / 85 \mathrm{~g}$ muscle) when two-stage comminution process was employed (Lee and Toledo, 1979). Potato starch can be added to improve structural integrity and make fish sausage firmer (Kasapis et al., 2003). Lower values were recorded for hardness, gumminess, chewiness, and fracturability when added tofu powder to lean frankfurters.

Table 3. Texture profile analysis (TPA) results of fish sausage during storage

\begin{tabular}{cllllll}
\hline Parameters(N) & Hardness & Springiness & Cohesiveness & Chewiness & Resilience & Adhesiveness \\
\hline T1 & $29.65 \pm 1.51^{\mathrm{ab}}$ & $0.84 \pm 0.03^{\mathrm{a}}$ & $0.23 \pm 0.02^{\mathrm{a}}$ & $5.63 \pm 0.77^{\mathrm{a}}$ & $0.07 \pm 0.01^{\mathrm{a}}$ & $-0.12 \pm 0.13^{\mathrm{a}}$ \\
T3 & $32.19 \pm 4.37^{\mathrm{a}}$ & $0.83 \pm 0.03^{\mathrm{a}}$ & $0.19 \pm 0.03^{\mathrm{ab}}$ & $4.96 \pm 0.50^{\mathrm{ac}}$ & $0.06 \pm 0.01^{\mathrm{a}}$ & $-0.07 \pm 0.11^{\mathrm{a}}$ \\
T6 & $29.67 \pm 4.84^{\mathrm{ab}}$ & $0.83 \pm 0.07^{\mathrm{a}}$ & $0.16 \pm 0.02^{\mathrm{b}}$ & $3.97 \pm 0.57^{\mathrm{bc}}$ & $0.06 \pm 0.01^{\mathrm{a}}$ & $-0.15 \pm 0.14^{\mathrm{a}}$ \\
T8 & $24.39 \pm 3.98^{\mathrm{b}}$ & $0.81 \pm 0.06^{\mathrm{a}}$ & $0.17 \pm 0.03^{\mathrm{ab}}$ & $3.44 \pm 0.89^{\mathrm{bd}}$ & $0.06 \pm 0.01^{\mathrm{a}}$ & $-0.15 \pm 0.15^{\mathrm{a}}$ \\
T10 & $23.73 \pm 7.8^{1 \mathrm{~b}}$ & $0.79 \pm 0.13^{\mathrm{a}}$ & $0.18 \pm 0.09^{\mathrm{ab}}$ & $3.32 \pm 1.71^{\mathrm{b}}$ & $0.07 \pm 0.04^{\mathrm{a}}$ & $-0.11 \pm 0.11^{\mathrm{a}}$ \\
T13 & $31.55 \pm 3.30^{\mathrm{a}}$ & $0.83 \pm 0.06^{\mathrm{a}}$ & $0.15 \pm 0.02^{\mathrm{b}}$ & $4.03 \pm 0.30^{\mathrm{bcd}}$ & $0.06 \pm 0.01^{\mathrm{a}}$ & $-0.18 \pm 0.13^{\mathrm{a}}$ \\
T15 & $33.92 \pm 3.75^{\mathrm{a}}$ & $0.78 \pm 0.06^{\mathrm{a}}$ & $0.18 \pm 0.04^{\mathrm{a}}$ & $4.64 \pm 0.80^{\mathrm{ad}}$ & $0.07 \pm 0.02^{\mathrm{a}}$ & $-0.18 \pm 0.16^{\mathrm{a}}$ \\
\hline
\end{tabular}

Different superscript letters within the same column represents significant difference $(p<0.05), n=10$ 


\section{Assessment shear test (Warner-Bratzler)}

The mean texture scores from the Warner Bratzer compression tests press peak values are summarized in Table 4. The shear force values of surimi sausage were arranged between $10.17 \mathrm{~N}$ and $12.15 \mathrm{~N}$. The firmness values were between 2.69 and 3.34. The firmness values of sausage were decreasing due to time storage. Except the peak in T3 no significant difference was determined $(P>0.05)$. The texture of formulated flesh is dependent upon composition and processing conditions employed. Furthermore, these factors may be influenced by product flesh formation, which also depends on salt activation and heat coagulation of myofibrillar muscle proteins (Terrell et al., 1981). Troy et al. (1999) concluded that blends, in particular those using tapioca starch, oat fiber and whey protein, when formulated together, bind and retain water to produce a tenderer product, thereby reducing shear forces. Ho et al. (1997) reported that the addition of tofu powder to lean frankfurters improved product texture.
These results are in agreement with other numerous studies where the replacement of meat muscle (and fat) resulted in a marked decrease in product hardness (Crehan et al., 2000; Pietrasik and Duda 2000). Similarly, Desmond and Kenny (1998) found that hardness and shear force of frankfurters significantly decreased with increasing addition of beef heart surimi. Similarly, in this study statistical analysis of pasteurized surimi sausage systems showed that all periods derived for shear force were significant $(P<0.05)$. These results were similar to the study of Moreira et al. (2002) who prepared emulsified sausage from tilapia fillets to determine their textural parameters. Among texture attributes, firmness and shear force are important properties for the consumer because they determine the texture acceptability of a product (Chambers and Bowers, 1993). There is a cut-off point below which the textures of many comminuted food products such as meat balls, frankfurter and sausages would be unacceptable (Yu and Yeang, 1993; Nurul et al., 2008).

Table 4. Shear test (Warner Bratzler) results of fish sausage during storage

\begin{tabular}{lcc}
\hline Days & Cutting Strength $(\mathbf{N})$ & Work of Shear $(\mathbf{N})$ \\
\hline T1 & $3.21 \pm 0.39^{\mathrm{ab}}$ & $10.39 \pm 0.76^{\mathrm{a}}$ \\
T3 & $3.60 \pm 0.57^{\mathrm{b}}$ & $12.15 \pm 1.21^{\mathrm{b}}$ \\
T6 & $3.07 \pm 0.77^{\mathrm{ab}}$ & $10.69 \pm 1.61 \mathrm{ac}$ \\
T8 & $3.34 \pm 0.78^{\mathrm{ab}}$ & $11.80 \pm 1.26^{\mathrm{bc}}$ \\
T10 & $3.17 \pm 0.40^{\mathrm{ab}}$ & $11.46 \pm 0.69^{\mathrm{abc}}$ \\
T13 & $3.23 \pm 0.33^{\mathrm{ab}}$ & $11.34 \pm 0.76^{\mathrm{abc}}$ \\
T15 & $2.69 \pm 0.21^{\mathrm{a}}$ & $10.17 \pm 0.43^{\mathrm{a}}$ \\
\hline
\end{tabular}

Different superscript letters within the same column represents significant difference $(p<0.05), n=10$

\section{Assessment of sensory analysis}

The sensory characteristics in each group were monitored over 13 days (Table 5). Results show that significant effects were not observed on spicy odour and juiciness and in visible fat during the storage. On the first day of storage perceived hardness, taste and appearance received the highest scores (Table 5). Significant differences in perceived spicy odour and juiciness could be explained by the volatile compounds and microbial loads as observed in a previous study (FernándezFernández et al. 2002). The effects of storage time on odour, bitterness, taste, and rancidity can be observed as increasing. Thus was explained by comparing the differences between the last week and the first week. The fish odour intensity increased over time as a result of off-odours, such as acidity and rancidity, these factors were observed to increase but they were still with in the acceptable range.
The perceived hardness, appearance, taste, bitter flavour declined with time storage. Other descriptors that increased during storage were: fish odour, spoiled odor, fattiness, bitterness, rancidity but showed no significant differences in first week ( $p>0.05$ ) except in the case of juiciness attribute. Gomez-Guillen and Borderias (1996) observed that the hydrated starch granules adhered to the matrix formed by the squid muscle proteins and contributed to the overall structural cohesion. At temperatures higher than $60^{\circ} \mathrm{C}$, starch gelatinized and produced a planar mesh that spread throughout the gel matrix. Similar structural changes in added starch in our sausage products during cooking and subsequent effect on the sensory properties of surimi sausages are expected. The reported scores were the panel means values. Sensorial panel score of 5 was defined as the limit of some attributes (for appearance, hardness and taste) for acceptance limit so the sausages were not determined as spoiled according to the sensorial results. 
Table 5. Sensory analysis results of fish sausage during storage

\begin{tabular}{lcccccc}
\hline Attributes & T1 & T3 & T6 & T8 & T10 & T13 \\
\hline Appearance & $9.0 \pm 0.10^{\mathrm{a}}$ & $8.8 \pm 0.04^{\mathrm{a}}$ & $8.6 \pm 0.05^{\mathrm{a}}$ & $7.2 \pm 0.02^{\mathrm{b}}$ & $6.5 \pm 0.00^{\mathrm{c}}$ & $6.0 \pm 0.10^{\mathrm{c}}$ \\
Visible fat & $0.0 \pm 0.00^{\mathrm{a}}$ & $0.0 \pm 0.00^{\mathrm{a}}$ & $0.0 \pm 0.00^{\mathrm{a}}$ & $0.0 \pm 0.00^{\mathrm{a}}$ & $0.0 \pm 0.00^{\mathrm{a}}$ & $0.0 \pm 0.00^{\mathrm{a}}$ \\
Hardness $^{\star}$ & $8.0 \pm 0.02^{\mathrm{a}}$ & $7.8 \pm 0.04^{\mathrm{b}}$ & $7.8 \pm 0.04^{\mathrm{b}}$ & $7.0 \pm 0.00^{\mathrm{b}}$ & $6.8 \pm 0.00^{\mathrm{c}}$ & $6.5 \pm 0.10^{\mathrm{d}}$ \\
Fish odour & $4.0 \pm 0.00^{\mathrm{a}}$ & $4.0 \pm 0.00^{\mathrm{a}}$ & $4.0 \pm 0.00^{\mathrm{a}}$ & $4.2 \pm 0.10^{\mathrm{b}}$ & $4.2 \pm 0.10^{\mathrm{b}}$ & $4.2 \pm 0.10^{\mathrm{b}}$ \\
Spicy odour & $1.0 \pm 0.00^{\mathrm{a}}$ & $1.0 \pm 0.00^{\mathrm{a}}$ & $1.0 \pm 0.00^{\mathrm{a}}$ & $1.00 \pm 0.00^{\mathrm{a}}$ & $1.0 \pm 0.00^{\mathrm{a}}$ & $1.0 \pm 0.00^{\mathrm{a}}$ \\
Spoiled odour & $0.0 \pm 0.00^{\mathrm{a}}$ & $0.0 \pm 0.00^{\mathrm{a}}$ & $0.0 \pm 0.00^{\mathrm{a}}$ & $0.0 \pm 0.00^{\mathrm{a}}$ & $1.0 \pm 0.00^{\mathrm{b}}$ & $1.0 \pm 0.00^{\mathrm{b}}$ \\
Taste & $9.5 \pm 0.05^{\mathrm{a}}$ & $9.5 \pm 0.05^{\mathrm{a}}$ & $9.0 \pm 0.00^{\mathrm{b}}$ & $8.5 \pm 0.00 \mathrm{c}$ & $7.0 \pm 0.00^{\mathrm{d}}$ & $7.0 \pm 0.00^{\mathrm{d}}$ \\
Fattiness & $1.0 \pm 0.00^{\mathrm{a}}$ & $1.0 \pm 0.00^{\mathrm{a}}$ & $1.0 \pm 0.00^{\mathrm{a}}$ & $1.00 \pm 0.00^{\mathrm{a}}$ & $2.0 \pm 0.00^{\mathrm{b}}$ & $2.0 \pm 0.00^{\mathrm{b}}$ \\
Juiciness & $2.0 \pm 0.00^{\mathrm{a}}$ & $2.0 \pm 0.00^{\mathrm{a}}$ & $2.0 \pm 0.00^{\mathrm{a}}$ & $2.00 \pm 0.00^{\mathrm{a}}$ & $2.5 \pm 0.00^{\mathrm{b}}$ & $2.0 \pm 0.00^{\mathrm{a}}$ \\
Acidic taste & $0.0 \pm 0.00^{\mathrm{a}}$ & $0.0 \pm 0.00^{\mathrm{a}}$ & $0.0 \pm 0.00^{\mathrm{a}}$ & $0.00 \pm 0.00^{\mathrm{a}}$ & $1.0 \pm 0.00^{\mathrm{b}}$ & $1.0 \pm 0.00^{\mathrm{b}}$ \\
Bitterness & $1.5 \pm 0.00^{\mathrm{a}}$ & $1.5 \pm 0.00^{\mathrm{a}}$ & $1.0 \pm 0.00^{\mathrm{b}}$ & $1.0 \pm 0.00^{\mathrm{b}}$ & $1.0 \pm 0.00^{\mathrm{b}}$ & $1.0 \pm 0.00^{\mathrm{b}}$ \\
Rancidity & $0.0 \pm 0.00^{\mathrm{a}}$ & $0.0 \pm 0.00^{\mathrm{a}}$ & $0.0 \pm 0.00^{\mathrm{a}}$ & $0.00 \pm 0.00^{\mathrm{a}}$ & $0.0 \pm 0.00^{\mathrm{a}}$ & $1.0 \pm 0.00^{\mathrm{b}}$ \\
\hline
\end{tabular}

Different superscript letters within the same rowrepresents significant difference $(p<0.05)$

Different superscript letters within the same column represents significant difference $(p<0.05)$

${ }^{*}$ Acceptability limit for appearance, hardness and taste score was 5 . Rest are giving the amount of the attributes assessed by the panelists

\section{Assessment of colour measurement}

Colour is one of the sensory properties that can easily affect the consumer opinions. The colours of meat sausages are generally red or pink colours. So by using coloring same meat sausage colour was performed in surimi sausage. When the values of each period were compared, no statistical difference was observed $(P>0.05)$ in $a^{*}$ and $b^{*}$ values during the storage. In the current study $L^{*}, a^{*}$ and $b^{*}$ values were ranged between; 67.95-72.02, 5.64-5.54 and 15.05-14.50, respectively. In the study of Gimeno et al. (2001), the color values of traditional meat sausage were determined as follows; for $L^{*}$ value 56.14 , for $a^{*}$ value 16.85 and for $b^{*}$ value 10.63 . But in fish sausages the $L^{*}$ value varied between 67.95 and 72.02 like the study of Dincer et al (2007). Big differences were determined between redness $\left(a^{*}\right)$ and yellowness values $\left(b^{*}\right)$ when compared with meat sausages. Fish sausages were determined to be much less red and much more yellow.

While the values for $L^{*}$ were increased, $a^{*}$ and $b^{*}$ were decreased during the storage time without showing any significant differences. Similar colour results can be seen in the study by Koizumi and Nonaka (1980). Cardoso et al. (2008) also investigated the development of healthy low-fat fish sausage; similar colour results were observed in their experiments.

\section{CONCLUSION}

As a conclusion, it was determined that saithe flesh can be used sufficiently to prepare a surimi product and by using that product successful fish sausage can be produced. Textural properties and the sensorial results approved that statement in the current study. For future studies increasing shelf life should be the main target. Although double pasteurization technique was used still for 15 days shelf life is not enough for these types of emulsified products so in future studies it is better to focus on studies about additives and packaging techniques.

\section{ACKNOWLEDGEMENT}

Part of this study was presented as a poster presentation at 3rd Joint Trans Atlantic Fisheries Technology Conference (39th WEFTA Meeting), Copenhagen, Denmark. Special thanks to the R\&D team of PInar Meat Company for their support. 


\section{REFERENCES}

AOAC, 1990. Official method reference: Official Methods of Analysis of the AOAC International, Arlington, VA, 15th ed., 985.22

AOAC, 1995. Official Methods of Analysis $16^{\text {th }}$ ed. AOAC International, Arlington, VA., AOAC, Chapter 43.

Ariyapitun, T., Mustapha, T. \& Clarkea, D. (1999). Microbial shelf-life determination of Vacuum-packaged fresh beef treated with polylactic acid lactic acid and nisin solutions. Journal of Food Protection, 62:913-920. doi: 10.4315/0362-028X-62.8.913

Bligh, E.G. \& Dyer, W.J. (1959). A rapid method of total lipid extraction and purification. Canadian Journal of Biochemistry and Physiology. 37: 911917. doi: 10.1139/059-099

Carballo, J., Fernandez, P., Barreto, G., Solas, M. T. \& Jime'Nez- Colmenero F. (1996). Morphology and texture of bologna sausage as related to content of fat, starch and egg white. Journal of Food Science, 61(3):652655. doi: 10.1111/j.1365-2621.1996.tb13179.x

Cardosa, C., Mendes, R. \& Nunes, M. L. (2008). Development of a healthy lowfat fish sausage containing dietary fibre. International Journal of Food Science and Technology, 43 (2): 276-283 doi: 10.1111/j.1365-2621.2006.01430.x

Chambers, E.N. \& Bowers, J.R. (1993). Consumer perception of sensory quality in muscle Foods. Food Technology, 47: 116-120. Chin, K.B. Keeton, J.T., Longnecker, M.T. \& Lamkey, J.W. (1998). Functional, textural and microstructure properties of low fat bologna (model system) with a konjac blend. Journal of Food Science. 63:801-807.

doi: 10.1111/j.1365-2621.1998.tb17904.x

Crehan, C.M., Hughes, E., Troy, D.J. \& Buckley, D.J. (2000). Effects of fat leve and maltodextrin on the functional properties of frankfurters formulated with 5, 12 and $30 \%$ fat. Meat Science, 55:463-469. doi: 10.1016/S0309-1740(00)00006-

Dawkins, N.L., Gager, J., Cornillon, J.P., Kim, Y., Howard, H. \& Phelps, O (2001). Comparative studies on the physicochemical properties and hydration behavior of oat gum and oat trim in meat based patties. Journal of Food Science, 66:1276-1282. doi: 10.1111/j.1365-2621.2001.tb15201.x

De Deckere, E.A.M., Korver, O., Verschuren, P.M. \& Kantan, M.B. (1998) Health aspects of fish and $n-3$ polyunsaturated fatty acids from plant and marine origin, European Journal of Clinical Nutrition, 52: 749-753. doi: 10.1016/0309-1740(86)90009-4

Desmond, E.M. \& Kenny, T. (1998). A. Preparation of surimi-like extract from beef hearts and its utilisation in frankfurters. Meat Science, 50:81-89. doi: 10.1016/S0309-1740(98)00018-7

Dincer, T. Çakli, S. \& Kilinc B. (2007). Mezgit (Pollachius Virens) Filetolarından Balık Sosis Üretimi Ve Soğuk Muhafazada Kimyasal Ve Mikrobiyal Kalite Kontrolü. XIV. Ulusal Su Ürünleri Sempozyumu, 4-7 Eylül. Mugla, Turkey.

Dincer, T. (2008). Production of fish sausage using rainbow trout fillets and determination the quality changes in cold storage conditions. Ege University Natural Science Ins. PhD. Thesis.

Dincer, T. \& Cakli, S. (2010). Textural and Sensory Properties of Fish Sausage from Rainbow Trout. Journal of Aquatic Food Product Technology, 19.238-248 doi: 10.1080/10498850 2010.509539

Dincer, T. \& Cakli, S. (2012). Turkish Patent Institute National Patent for Fish sausage Production. Patent No: TR 2009 02207B.

FAO. (1986). FAO Food and Nutrition paper manuals of food quality contro food analysis: quality, adulteration, and tests of identity. Food and Agriculture Organization of the United Nations. Rome, Italy.

FDA. (1992). Method 196: Bacterial Analytical Manual. $7^{\text {th }}$ ed. FDA, Arlington VA.
Fernández-Fernández, E., Vázquez-Odériz, M.L. \& Romero-Rodriguez, M.A (2002). Effects of manufacturing process variables on the physicochemical and sensory characteristics of Galician chorizo sausage. Journal of Science Food and Agriculture, 82:273-279. doi: 10.1002/jsfa.1023

Gimeno, O., Astiasaran, I., Bello J. (2001). Calcium ascorbate as a potential partial substitute for $\mathrm{NaCl}$ in dry fermented sausages: effect on colour, texture and hygienic quality at different concentrations. Meat Science, 57:23-29. doi: 10.1016/S0309-1740(00)00070-X

Gomez-Guillen, C. \& Borderias, J. (1996). Effect of heating temperature and sodium chloride concentration on ultrastructure and texture of gels made from giant squid (Dosidicus gigas) with addition of starch, k-carrageenan and egg white. Zeitschrift für Lebensmittel-Untersuchung und -Forschung. 202: 221-227. doi: 10.1007/BF01263544

Gray J.I, Gomaa E.A \& Buckley D.J.(1996). Oxidative quality and shelf life of meats. Meat Science 43: 111-123. doi: 10.1016/0309-1740(96)00059-9

Harrigan, W.F. \& Mccance, M.E. (1976). Laboratory Methods in Food and Dairy Microbiology. London: Academic Press Inc.

Ho, K.G., Wilson, L.A., \& Sebranek, J.G. (1997). Dried soy tofu powder effects on frankfurters and pork sausage patties. Journal of Food Science, 62:434-437. doi: 10.1111/j.1365-2621.1997.tb04020.x

Hughes, E., Cofrades, S. \& Troy, D. (1997). Effects of fat level, oat fiber and carrageenan on frankfurters formulated with 5,12 and $30 \%$ fat. Meat Science, 45:273-281. doi: 10.1016/S0309-1740(96)00109-X

ICMSF (1978). Microorganisms in Foods (Vol. 2). The International Commission on Microbiological Specifications for Foods Toronto, Canada.

Jin, S.K., Kim, I. S., Jung, H. J., Kim, D. H., Choi, Y. J. \& Hur, S. J. (2007). The Development of Sausage Including Meat from Spent Laying Hen Surimi. Poultry Science, Volume 86: 2676-2684. doi: 10.3382/ps.2006-00451

Kasapis, S., Al-Oufi, H.S. \& Al-Maamari, S. 2003). Minced fish products of improved eating quality. Irish Patent, S2003/0921.

Kim, J.S. \& Park, J.W. (2006). Mince from seafood by-products and surimi as ingredients. In Maximizing the Value of Marine By-Products. (Ed.) Shahidi, F. CRC Woodhead Press, Cambridge, England. Pp 196-228

Koizumi, C. \& Nonaka, J. (1980). Color Development of Fish Sausage with Ferrihemochrome-forming nitrogenous Bases as possible Substitues for nitrite. Bulletin of the Japanese Society for the Science of Fish, 46:373380

Konno, K. (2005). New developments and trends in kababoko and related research in Japan. In: J.W. Park, (Ed), Surimi and surimi seafood (pp847868), CRC Press, Taylor \& Francis

Kris-Etherton, P.M., Krummel, D., Russell, M.E., Dreon, D., Mackey, S., Borchers, J., \& Wood, P.O. (1988). The effect of diet on plasma lipids, lipoproteins and coronary heart disease, Journal of the American Dietetic Association, 88:1373-1400.

Lanier, T.C. (1986). Functional properties of surimi. Food Technology, 40:107114124

Lee, C.M. (1986). Surimi manufacturing and fabrication of surimi based products. Food Technology 40:115-124

Lee, C.M. \& Toledo, R.T. (1979). Processing and ingredient influences on texture of comminuted fish muscle. Journal of Food Science, 44:16151618. doi: 10.1111/j.1365-2621.1979.tb09101.x

Llull P., Simal, S., Benedito,J. \& Rosselló C. (2002). Evaluation of textural properties of a meat-based product (sobrassada) using ultrasonic techniques. Journal of Food Engineering. 53:279-285 doi: 10.1016/S0260-8774(01)00166-2 
Ludorff, W. \& Meyer, V. (1973). Fische und Fischerzeugnisse. Verlag Pau Parey in Hamburg und Berlin. ISBN 348971914 X.

Mossel, D.A. \& Moreno Garcia, B. (1985). Técnicas para el análisis microbiológico de los alimentos. In: Microbiología de los Alimentos. $p$ 214-272.

Moreira, R.T., Lemos, A.L.D.S.C. \& Cristianini, M. (2002). Effect of fat content and soy isolate protein on texture of fish emulsified type sausage. 3-7 Jun 2002 Annual Meeting and Food Expo - Anaheim, California USA.

Murakawa, Y., Benjakul, S., Visessanguan, W. \& Tanaka, M. (2003). Inhibitory effect of oxidized lipid on thermal gelation of Alaska Pollack (Theragra chalcogramma) surimi. Food Chemistry, 82:455-463. doi: 10.1016/S0308-8146(03)00103-1

Murphy, S.A., Solomon, B.M., Meng, S.N., Copeland, J.M., Shaw, T.J., \& Ferry, J.L. (2014). Geochemical production of reactive oxygen species from biogeochemically reduced Fe. Environmental Science and Technology. 48:3815-3821. doi: 10.1021/es4051764

Nishimoto, S. I., Ohtani, B., Kajiwara, H. \& Kagiya, T. (1985). Correlation of the crystal structure of titanium dioxide prepared from titanium tetra-2 propoxide with the photocatalytic activity for redox reactions in aqueous propan-2-ol and silver salt solutions. Journal of the Chemical Society, 81(1):61-68. doi: 10.1039/F19858100061

Nurul, H., Noryati, I. \& Alistair, T.L.J. (2008). Physicochemical properties of Malaysian commercial beef frankfurter. 23rd Scientific Conference of the Nutrition Society of Malaysia, Crowne Plaza Mutiara Hotel, Kuala Lumpur, 27-28 March 2008.

Orellana, L.E., Negron, E., Chaparro, M. \& Kubaryk. J. (1999). Development and shelf life determination of a fresh fish sausage make with. 1999 IFT Annual Meeting, Chicago, USA - July 24-28.

Park, W. \& Morrissey, M.T. (2000). Manufacturing of surimi from light muscle fish. In: J.W. Park, (Ed), Surimi and Surimi Seafood, Marcel Dekker Inc. New York, pp. 23-58.

Pietrasik, K. \& Duda, Z. (2000). Effect of fat content and soy protein/ carrageenan mix on the quality characteristics of comminuted, scalded sausages. Meat Science, 56(2):181-188 doi: 10.1016/S0309-1740(00)00038-3

Prabhu, G.A. \& Sebranek, J.G. (1997). Quality characteristics of ham formulated with modified corn starch and kappa-carrageenan. Journal of Food Science, 62:198-202. doi: 10.1111/j.1365-2621.1997.tb04399.x

Ripoche, A., Le Guern, L., Martin, J.L., Taylor, R.G. \& Vendeuvre, J. -L. (2001) Sausage structure analysis. Journal of Food Science, 66(5):670-674. doi: 10.1111/j.1365-2621.2001.tb04619.x

Sanderson, G.R. (1990). Gellan gum. In: P. Harris, (Ed), Food gels, Elsevier New York , pp. 201-232.

Schormuller, J. (1968). Handbuch der Lebensmittelchemie (Band III/2). Berlin Heidelberg, New York: Springer Verlag.
Schubring, R. (2002). Texture measurement on gutted cod during storage in ice using a hand-held instrument. Informationen für die Fischwirtschaft aus der Fischereiforschung, 49:25-27.

Schubring, R. (2003). Colour measurement for the determination of the freshness of fish. In: J.B. Luten, J. Oehlenschlager and G. Olafsdottir, (Ed), Quality of fish from catch to consumer: Labelling, monitoring and traceability, (pp. 251-263). The Netherlands, Wageningen: Academic Publishers,

Shand, P.J. (2000). Textural, water holding and sensory properties of low-fat pork bologna with normal or waxy starch hull-less barley. Journal of Food Science, 65:101-107. doi: 10.1111/j.1365-2621.2000.tb15963.x

Schormüller, J. (1969). Handbuch der Lebensmittel Chemie. Band IV. Fette und Lipoide (LIPIDS), SpringerVerlag, New York, Heidelberg, Berlin: 872-878.

Su, Y.K., Bowers J.A. \& Zayas J.F. (2000). Physical characteristics and microstructure of reduced-fat frankfurters as affected by salt and emulsified fats stabilized with nonmeat proteins. Journal of Food Science, 65:123-128. doi: 10.1111/j.1365-2621.2000.tb15966.x

Tarladgis, B.G., Watts, B.M., Younathan, M.S. \& Dugan, L.Jr. (1960). A Distillation method for the quantitative determination of malonaldehyde in rancid foods. Journal of the American Oil Chemists' Society, 37:44-48.

Terrell, R.N., Ming, C.G. Jacobs, J.A. Smith G.C. \& Carpenter Z.L. (1981) Effect of chloride salts, acid phosphate and electrical stimulation on $\mathrm{pH}$ and moisture loss from beef clod muscles. Journal of Animal Science, 53:658.

Toyoda, K., Kimura, I., Fujita, T., Noguchi, S.F. \& Lee, C.M. (1992). Surimi manufacturing from whitefish. In T. C. Lanier, \& C.M. Lee (Eds.), Surimi Technology (pp. 79-112). New York: Marcel Dekker.

Troy, D.J., Desmond, E.M. \& Buckley, D.J. (1999). Eating quality of low-fat beef burgers containing fat-replacing functional blends. Journal of Food of Science and Agriculture, 79:507-516. doi: 10.1002/(SICI)1097-0010(19990315)79:4<507::AID-JSFA209>3.0.CO;2-6

Trautwein, E.A. (2001). N-3 fatty acids-physiological and technical aspects for their use in food. European Journal of Lipid Science Technology, 103: 45-55.

doi: 10.1002/1438-9312(200101)103:1<45::AID-EJLT45>3.0.CO;2-9

Vyncke, W. (1996). Comparison of the official EC method for the determination of total volatile bases in fish with routine methods. Archiv für Lebensmittelhygiene, 47:110-112.

Xiong, Y.L., Noel, D.C. \& Moody, W.G. (1999). Textural and sensory properties of low-fat beef sausages with added water and polysaccharides as affected by $\mathrm{pH}$ and salt. Journal of Food Science, 64(3):550-554. doi: 10.1111/j.1365-2621.1999.tb15083.x

Yu, S.Y. \& Yeang, S.B. (1993). Effects of type of starch on the quality of fishballs, In Liang, O.B., Buchanan, A., \& Fardiaz, D (Ed.). Development of Food Science and Technology in Southeast Asia (pp 325-332). Indonesia Bogor: IPB Press. 